\title{
Recombinants of Bean common mosaic virus (BCMV) and Genetic Determinants of BCMV Involved in Overcoming Resistance in Common Bean
}

\author{
Xue Feng, Alan R. Poplawsky, Olga V. Nikolaeva, James R. Myers, and Alexander V. Karasev
}

First, second, third, and fifth authors: Department of PSES, University of Idaho, Moscow; fourth author: Department of Horticulture, Oregon State University, Corvallis; and fifth author: Bioinformatics and Computational Biology Program, University of Idaho, Moscow. Accepted for publication 2 January 2014.

\begin{abstract}
Feng, X., Poplawsky, A. R., Nikolaeva, O. V., Myers, J. R., and Karasev, A. V. 2014. Recombinants of Bean common mosaic virus (BCMV) and genetic determinants of BCMV involved in overcoming resistance in common bean. Phytopathology 104:786-793.

Bean common mosaic virus (BCMV) exists as a complex of strains classified by reactions to resistance genes found in common bean (Phaseolus vulgaris); seven BCMV pathotypes have been distinguished thus far, numbered I to VII. Virus genetic determinants involved in pathogenicity interactions with resistance genes have not yet been identified. Here, we describe the characterization of two novel field isolates of BCMV that helped to narrow down these genetic determinants interacting with specific $P$. vulgaris resistance factors. Based on a biological characterization on common bean differentials, both isolates were classified as belonging to pathotype VII, similar to control isolate US10, and both isolates exhibited the B serotype. The whole genome was sequenced for

both isolates and found to be 98 to $99 \%$ identical to the BCMV isolate RU1 (pathotype VI), and a single name was retained: BCMV RU1-OR. To identify a genetic determinant of BCMV linked to the BCMV pathotype VII, the whole genome was also sequenced for two control isolates, US10 and RU1-P. Inspection of the nucleotide sequences for BCMV RU1-OR and US10 (both pathotype VII) and three closely related sequences of BCMV (RU1-P, RU1-D, and RU1-W, all pathotype VI) revealed that RU1-OR originated through a series of recombination events between US10 and an as-yet-unidentified BCMV parental genome, resulting in changes in virus pathology. The data obtained suggest that a fragment of the RU1-OR genome between positions 723 and 1,961 nucleotides that is common to US10 and RU1-OR in the P1-HC-Pro region of the BCMV genome may be responsible for the ability to overcome resistance in bean conferred by the $b c-2^{2}$ gene. This is the first report of a virus genetic determinant responsible for overcoming a specific BCMV resistance gene in common bean.
\end{abstract}

Bean common mosaic virus (BCMV) and Bean common mosaic necrosis virus (BCMNV) belong to the genus Potyvirus in the family Potyviridae (1) and cause serious economic losses in common bean (Phaseolus vulgaris L.) $(8,33,42)$. Both are typical potyviruses, transmitted by several aphid species in a nonpersistent manner (33). BCMV and BCMNV are closely related, induce similar symptoms in bean, and exist as a complex of strains with multiple isolates which differ in their virulence on common bean cultivars. BCMV and BCMNV isolates are classified into seven pathotypes according to their reactions on 12 to 14 bean differentials with known combinations of resistance genes (5). All BCMV and BCMNV strains are seed-transmitted in bean, which is the main reason for the worldwide distribution and importance of this virus (33).

Five resistance genes govern interactions of BCMV and BCMNV isolates with common bean-one strain-nonspecific dominant $I$ gene, and four strain-specific recessive genes: $b c-u$, $b c-1, b c-2$, and $b c-3$ (5). Two of these recessive resistance genes have two resistance alleles each $\left(b c-1 / b c-1^{2}\right.$ and $\left.b c-2 / b c-2^{2}\right)$ for a total of seven genes or alleles that interact with the different pathotypes of BCMV or BCMNV. The strain-specific resistance genes are unlinked but $b c-u$ is required for expression of resistance by the other $b c$-genes. The dominant $I$ gene confers

Corresponding author: A. V. Karasev; E-mail address: akarasev@uidaho.edu

*The $e$-Xtra logo stands for "electronic extra" and indicates that Figures 2 and 3 appear in color online.

http://dx.doi.org/10.1094/PHYTO-08-13-0243-R

(c) 2014 The American Phytopathological Society immunity or a hypersensitive response to all isolates of BCMV and BCMNV (i.e., no detectable virus replication occurs). If a BCMNV isolate is inoculated into an I-gene-carrying cultivar, a necrotic reaction occurs, regardless of the temperature, varying from limited vein necrosis on the inoculated leaf to a severe, whole-plant necrosis, called "black root syndrome". This reaction is called temperature-insensitive necrosis (TIN). When such necrotic reaction occurs, no virus replication is detected in leaf tissues surrounding necrotic tissue and no virus transmission through seed can be detected, resulting in a resistance reaction at the plant level. The necrotic reaction may be mitigated or prevented if the $I$ gene is "protected" in the presence of one of the three recessive genes with various alleles $\left(b c-1, b c-1^{2}, b c-2, b c-2^{2}\right.$, or $b c-3)$. Whereas $b c-u$ is necessary for expression of other strainspecific resistance genes, it is not required for protection of the $I$ gene by the strain-specific resistance genes. If a BCMV isolate is inoculated into an I-gene-carrying cultivar, no necrotic reaction occurs if the temperature stays $<30^{\circ} \mathrm{C}$; however, at $>30^{\circ} \mathrm{C}$, necrotic reaction may occur, which may be very similar to the necrotic reaction caused by BCMNV isolates. This type of reaction is called temperature-sensitive necrosis (TSN).

BCMNV isolates belong to pathotypes III and VI, and all have the A serotype as opposed to serotype B in BCMV isolates $(5,31,44,50)$. Both BCMV and BCMNV isolates will induce mosaic, leaf deformations, blistering, and sometimes severe stunting in susceptible bean cultivars $(5,31,33,44)$. Not all pathotype VI isolates have serotype A and induce TIN; RU1 isolate was described as a BCMV isolate with pathotype VI and the B serotype inducing TSN $(3,22,31)$. The genome regions of BCMV and $\mathrm{BCMNV}$ involved in interactions with either the $I$ gene or reces- 
sive genes are not yet mapped although, based on the analysis of $\mathrm{NL}-3 \mathrm{~K}$, a natural recombinant of BCMNV, the genome region in the P1 gene was found modulating symptom severity in common bean (22). Characterization of the pathogenicity determinants in $\mathrm{BCMV}$ and BCMNV responsible for interactions with resistance genes in common bean is currently hampered by the diversity of isolates and by the complexity of the biological assays, especially when recessive genes are studied. An additional complication is that, in some cases, nucleotide sequences determined for BCMV or BCMNV isolates were not complemented by concomitant biological experiments and, hence, are difficult to interpret now in terms of pathogenicity determinants.

Here, we report a systematic study of biological and molecular properties of several BCMV isolates from a large virus collection maintained in Prosser, WA. We also studied two unusual field isolates of BCMV that helped to initially map genetic determinants in the virus that interact with $b c-2^{2}$. Characterization of the biology and molecular properties of these isolates, and other isolates with the same or differing pathogenicity on bean differentials, allowed us to localize putative genetic determinants of pathogenicity interacting with the $b c-2^{2}$ gene.

\section{MATERIALS AND METHODS}

Virus sources, propagation, and purification. All reference BCMV and BCMNV isolates used in this work originated from the United States Department of Agriculture-Agricultural Research Service, Prosser, WA collection. BCMV isolates US10 and NY15P and BCMNV isolate TN1 were provided by Drs. P. Berger and P. Shiel; BCMV isolate RU1-P was provided by Dr. J. Crosslin. Two field isolates of BCMV, JMB and JMC, later named RU1-OR-B and RU1-OR-C, were collected from the Oregon State University Vegetable Research Farm, Corvallis

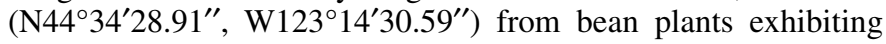
mild mosaic and stunting symptoms in summer 2011. The isolates appeared to be seedborne in the line L192, a brown-seeded dry bean with determinant growth habit most likely originally derived from interspecific hybridization work with $P$. coccineus conducted by H. Lamprecht $(11,19,20)$.

All virus isolates were propagated under greenhouse conditions in the bean 'Dubbele Witte' using mechanical inoculation. Leaf tissue was harvested 14 to 21 days postinoculation (dpi), and the virus was purified using a procedure described by Leiser and Richter (24), with some modifications. Briefly, $100 \mathrm{~g}$ of leaf tissue was homogenized in $100 \mathrm{ml}$ of cold extraction buffer (0.5 M potassium phosphate buffer, $\mathrm{pH} 7.5$, containing $0.02 \mathrm{M}$ sodium sulfite). Leaf homogenate was squeezed through cheesecloth and centrifuged at $6,000 \mathrm{rpm}$ for $15 \mathrm{~min}$. Triton X-100 was added to the supernatant to a final concentration of $3 \%$ (vol/vol). The mixture was stirred at $4{ }^{\circ} \mathrm{C}$ for $30 \mathrm{~min}$ and centrifuged at $30,000 \times g$ for $2 \mathrm{~h}$. The pellet was resuspended in a resuspension buffer $(0.5 \mathrm{M}$ potassium phosphate buffer, $\mathrm{pH} 7.5)$ and then centrifuged at $15,000 \times g$ for $15 \mathrm{~min}$. The supernatant was collected and laid over a cushion of $20 \%$ (wt/vol) sucrose (in deionized water), followed by a high-speed centrifugation at $50,000 \times g$ for $2 \mathrm{~h}$. The final pellet was resuspended in the storage buffer ( $0.25 \mathrm{M}$ potassium phosphate buffer, $\mathrm{pH} 7.5)$. The purified viruses were kept with the sodium azide preservative at $4{ }^{\circ} \mathrm{C}$ for later use.

Antibody production, enzyme-linked immunosorbent assay format, and Western blots. Polyclonal antisera against TN1, US10, and NY15P were raised in rabbits and in guinea pigs following a series of four to six immunizations, with the first one in the presence of complete Freund's adjuvant and all subsequent with the presence of incomplete Freund's adjuvant. The development of the virus-specific titer was monitored by indirect enzymelinked immunosorbent assay (ELISA), with purified homologous $\mathrm{BCMV}$ or BCMNV isolate captured on the ELISA plate. Two specific antisera were produced for each isolate, one in rabbit and one in guinea pig.

Triple-antibody sandwich (TAS)-ELISA tests were performed following the general protocol of Clark and Adams (4), with modifications described previously (17). Briefly, wells of Nunc MaxiSorp microtiter plates (Nunc, Rochester, NY) were coated with $100 \mu \mathrm{l}$ of the rabbit antiserum at 1:10,000 dilution in $20 \mathrm{mM}$ sodium carbonate buffer $(\mathrm{pH}$ 9.6). Plates were incubated with plant extracts for 16 to $20 \mathrm{~h}$ at $4^{\circ} \mathrm{C}$ and washed with phosphatebuffered saline plus Tween 20 (PBST), and an intermediate detecting antiserum from guinea pig at the appropriate concentration was applied to the wells. After incubation for $4 \mathrm{~h}$ at $37^{\circ} \mathrm{C}$ (or, alternatively, for 16 to $20 \mathrm{~h}$ at $4^{\circ} \mathrm{C}$ ), plates were washed extensively with PBST, and goat anti-guinea pig (Sigma A-5062) immunoglobulin $\mathrm{G}(\mathrm{IgG})$ conjugates with alkaline phosphatase at $1: 30,000$ dilution in PBST with $0.2 \%$ bovine serum albumen were added, and the plates were incubated $4 \mathrm{~h}$ at $37^{\circ} \mathrm{C}$ (or 16 to $20 \mathrm{~h}$ at $4^{\circ} \mathrm{C}$ ). After washing and adding p-nitrophenyl phosphate (Sigma) substrate, the color reaction was monitored by measuring absorbance at $405 \mathrm{~nm}$ using an ELISA reader (SpectraMax 190; Molecular Devices, Sunnyvale, CA). BCMV- or BCMNV-positive and negative samples were included in each ELISA experiment as controls. Samples were defined as positive if the absorbance value exceeded the healthy controls threefold.

For Western blots, purified virus preparations were mixed with the Laemmli Tris-sodium dodecyl sulfate (SDS) sample buffer and heated at $95^{\circ} \mathrm{C}$ for $4 \mathrm{~min}$, and proteins were separated on 4 to $20 \%$ gradient polyacrylamide gels using Laemmli's Tris-SDS protocol (Bio-Rad). Separated proteins were transferred onto a nitrocellulose membrane (Bio-Rad) as described previously (17). The membranes were incubated for $2 \mathrm{~h}$ with the respective guinea pig polyclonal antiserum following incubation with alkaline phosphatase conjugated goat anti-guinea pig IgG (Sigma A-5062). The immune complexes were revealed by incubating the membranes with 5-bromo-4-chloro-3'-indolyphosphate p-toluidine (BCIP)/ nitro-blue tetrazolium (NBT) substrate (Sigma) and the color reaction was stopped by washing them in water.

BCMV and BCMNV biological characterization on bean indicators. A set of bean differentials (5) representative of the various host groups (HGs) was evaluated for reaction to infection with BCMV and BCMNV isolates. The differentials (Table 1) included Dubbele Witte (HG 0), 'Stringless Green Refugee' (HG 1), 'Redlands Greenleaf C' (HG 2), 'Redlands Greenleaf B' (HG 3), 'Sanilac' (HG 4), 'IVT-7214' (HG 7), 'Jubila' (HG 9), 'Amanda' (HG 10), 'US92-1006' (HG 11), and 'IVT-7233' (HG 11). All biological experiments were conducted under greenhouse conditions, following mechanical inoculation of bean indicator plants at the primary leaf stage. When infected plants were used as inocula, 0.2-g samples were ground in mortars with pestles with $1 \mathrm{ml}$ of PBS $\left(4^{\circ} \mathrm{C}\right)$, and plant sap was clarified by low-speed centrifugation $(2,000 \times g)$ and then used for the mechanical inoculation of bean leaves dusted with carborundum powder. Purified virus preparations of three reference strains-NY15P (pathotype V), TN1 (pathotype VI), and US10 (pathotype VII)were included in this analysis as controls. Eleven bean differential lines carrying different resistant gene combinations (Table 1) were inoculated with each isolate in duplicate, and plants were placed in the greenhouse with standard summer-time growth conditions (16-h photoperiod and daytime and nighttime temperatures of 25 and $20^{\circ} \mathrm{C}$, respectively). Symptoms were recorded at 4.5 and 7.5 weeks postinoculation. In addition, at 4.5 weeks postinoculation, samples were collected for ELISA testing.

Cloning strategy, sequencing, and sequence analysis. The cloning strategy for all BCMV isolates was based on the initial amplification of three genome fragments through reverse-transcriptase polymerase chain reaction (RT-PCR) using degenerate primers developed for conserved areas of potyvirus genomes, as described by $\mathrm{Ha}$ et al. (10). Briefly, three pairs of degenerate 
primers were used to amplify conserved areas in the HC-Pro, CI, and NIb-3'-end regions. Once these initial fragments were cloned and sequenced, the remaining gaps were filled through RT-PCR using specific primers based on the sequences determined (Fig. 1). All primers used in this study are listed in Table 2. The wholegenome sequences for BCMV isolates have been deposited in the GenBank database under the following accession numbers: RU1OR-B (KF919297), RU1-OR-C (KF919298), US10 (KF919299), and RU1-P (KF919300).

Virus RNA was extracted as described previously (14). Reverse transcription was performed using $6 \mu \mathrm{l}$ of the total nucleic acid extract in a $50-\mu$ l reaction mixture that contained $5 \times$ first-strand buffer (Promega Corp.), $0.5 \mathrm{mM}$ each dNTP, $0.15 \mu \mathrm{M} \mathrm{N1T}$ primer, 24 units of RNase Out Ribonuclease Inhibitor (Promega Corp.), and 240 units of M-MLV RT (Promega Corp.). Before the reverse-transcription reaction, $6 \mu$ of RNA template was incubated at $70^{\circ} \mathrm{C}$ for $5 \mathrm{~min}$; then, the reverse-transcription mix was added. The profile used here consisted of incubation at $37^{\circ} \mathrm{C}$ for $60 \mathrm{~min}$ and $\mathrm{RT}$ deactivation at $70^{\circ} \mathrm{C}$ for $10 \mathrm{~min}$. All PCR reactions, except the $5^{\prime}$-end fragment amplification, were accomplished by Takara LA Taq in a 50- $\mu$ l reaction mixture that contained $10 \times$ LA buffer $(5 \mu \mathrm{l}), 0.2 \mathrm{mM}$ dNTP, $0.2 \mu \mathrm{M}$ each forward primer and reverse primer, 2.5 units of LA Taq, and $6 \mu 1$ of cDNA template. The PCR profile consisted of denaturing at $94^{\circ} \mathrm{C}$ for $2 \mathrm{~min} ; 35$ cycles of $94^{\circ} \mathrm{C}$ for $30 \mathrm{~s}, 55$ to $65^{\circ} \mathrm{C}$ for $30 \mathrm{~s}$ (depending on the melting temperature of primers used), and $72^{\circ} \mathrm{C}$ for 0.5 to $4.5 \mathrm{~min}$ (depending on the fragment length amplified); followed by a final extension for $10 \mathrm{~min}$ at $72^{\circ} \mathrm{C}$. The $5^{\prime}$ end of the viral genome was amplified using the $5^{\prime}$ rapid amplification of cDNA ends ( $5^{\prime}$-RACE) kit (Roche). The protocol followed the manufacturer's instructions. RNA extracted from purified virus prep was used as the template to synthesize the first-strand cDNA. The first-strand primer was $5^{\prime}$-RACE rev1 and the PCR reverse primer was 5'-RACE rev2 (Table 2).

All PCR products were purified from low-melting agarose gels and cloned into the plasmid vector pGEM-T Easy (Promega Corp.), as recommended by the manufacturer. Plasmid DNA was purified from transformed Escherichia coli XL2-Blue Ultracompetent cells (Aligent) using alkaline lysis, and clones containing inserts of expected size (based on primer positions) were identified by EcoR I digestion. Three independent clones for each RTPCR fragment were sequenced in both directions by GENEWIZ, Inc. (South Plainfield, NJ) using the M13F (-21) and M13R primers for initial sequencing and additional virus-specific primers for large fragments.

The sequences were initially analyzed using the BLASTn 2.2.17 (2) tool available at the National Center for Biotechnology Information (NCBI). Complete viral genomes were assembled using SeqMan (DNASTAR, Madison, WI). Open reading frames (ORFs) were identified using the ORF Finder program available at the NCBI (http://www.ncbi.nlm.nih.gov/gorf/gorf.html). Complete sequences of BCMV isolates were aligned using ClustralX (Ver. 2.0; Conway Institute, UCD, Dublin). Further analysis was conducted with the Recombination Detection Program v.4.16

TABLE 1. Disease and enzyme-linked immunosorbent assay (ELISA) reactions of bean differentials inoculated with Bean common mosaic virus (BCMV) strains ${ }^{\mathrm{a}}$

\begin{tabular}{|c|c|c|c|c|c|}
\hline Bean cultivar & Resistance genes & TN1 (VI) & US10 (VII) & JMB & JMC \\
\hline Dubbele Witte & None & $+/+$ & $+/+$ & $+/+$ & $+/+$ \\
\hline RGLC & $b c-u, b c-1$ & $+/+$ & $+/+$ & $+/+$ & $+/+$ \\
\hline Sanilac & $b c-u, b c-2$ & $+/+$ & $-1-$ & $-1-$ & $-1-$ \\
\hline Othello & $b c-u, b c-1^{2}, b c-2^{2}$ & $-1-$ & $+/+$ & $+/+$ & $+/+$ \\
\hline IVT7214 & $i, b c-u, b c-2, b c-3$ & $-1+$ & $-1-$ & $-1-$ & $-1-$ \\
\hline Jubila & $I, b c-1$ & nec/NA & $-1-$ & $-1-$ & $-1-$ \\
\hline IVT7233 & $I, b c-u, b c-1^{2}, b c-2^{2}$ & $-1-$ & $-1-$ & $-1-$ & $-1-$ \\
\hline
\end{tabular}

${ }^{a}$ Disease reaction is shown first as a numerator followed by ELISA reaction as a denominator. Two plants were inoculated per each BCMV strain; results shown were the same for both plants inoculated with each virus preparation. Numerator: $+=$ symptoms on inoculated bean; $-=$ no symptoms on inoculated bean; nec $=$ whole plant necrosis reaction. Denominator: + designates ELISA signal (absorbance at $405 \mathrm{~nm}$ ) in an infected plant exceeding healthy control $\geq 10$-fold; - designates ELISA signal in an infected plant equal to a healthy control; NA designates "not applicable", because the plant died before the test could be run.
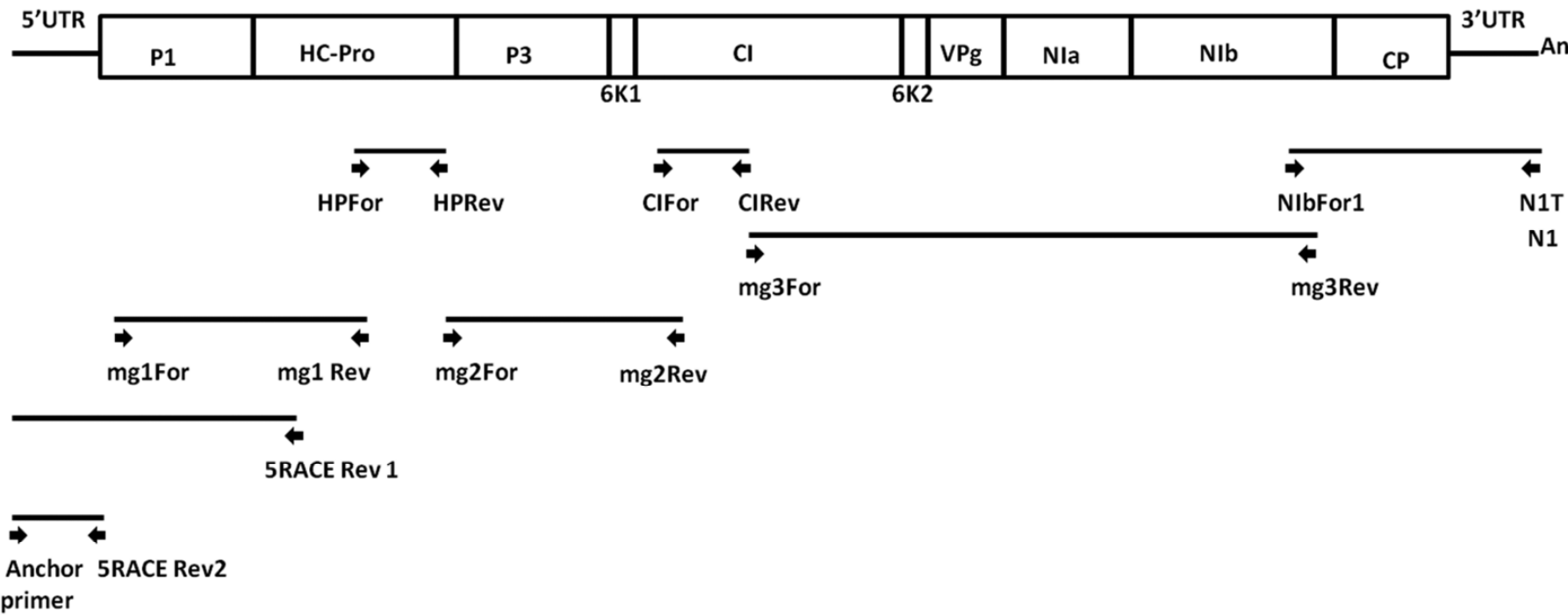

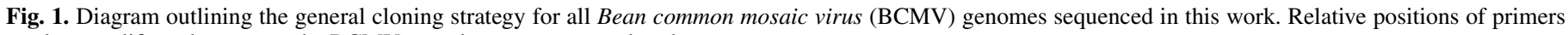
used to amplify and sequence the BCMV complete genome are also shown. 
(RDP4) (27). Further analysis for ClustalX-aligned sequences was performed by the program package RDP4.

\section{RESULTS}

Biological characterization. When tested on the 11 bean differential lines, both the JMB and JMC isolates of BCMV RU1OR showed identical disease reactions, producing typical mosaic, raised dark-green blistering, and growth retardation in susceptible bean varieties. Presence of BCMV in inoculated plants was confirmed with TAS-ELISA (Table 1), and it always matched the symptom expression. Reference strains NY15P (pathotype V), TN1 (pathotype VI), and US10 (pathotype VII) showed the expected susceptibility profiles with the differential lines based on their pathotypes. Both JMB and JMC isolates displayed susceptibility profiles identical to those of the pathotype VII reference strain, US10. No necrotic reactions were recorded in Jubila, Amanda, US 1006, and IVT 7233 bean, harboring the I gene, upon inoculation with either JMB or JMC isolates. Plants deemed to be negative for virus replication by TAS-ELISA, showed no disease symptoms. Some 'Othello' plants inoculated with either US10 or JMC virus preparations did not show mosaic or score positive with ELISA until 7.5 weeks postinoculation, indicating late or very slow virus spread.

Serological characterization of $\mathrm{BCMV}$ and $\mathrm{BCMNV}$ isolates. Both JMB and JMC isolates were subjected to a serological characterization in TAS-ELISA and Western blots, side by side with reference strains US10, NY15P, and TN1, to determine their serotype. In these experiments, all BCMV and BCMNV isolates were captured on the ELISA plate using anti-TN1, anti-US10, or
anti-NY15P rabbit antiserum, and were subsequently probed with different guinea-pig-detecting antibodies generated to specific isolates of BCMV or BCMNV mentioned above. Serological specificities of detecting antibodies were also tested using Western blots and were found to match the TAS-ELISA specificity. It should be noted that the titer of the antisera produced against all three viruses in either rabbits or guinea pigs was very high, and resulted in working dilutions for detecting antibodies of $1: 300,000$ to $1: 400,000$, providing a robust detection (and differentiation) tool for the BCMV strains studied. The serotyping data are summarized in Table 3. The anti-US10 guinea pig antiserum displayed universal specificity when used as a detecting antibody in TAS-ELISA, binding all isolates tested, including JMB and $\mathrm{JMC}$, and also the BCMNV isolate TN1. On the other hand, the anti-TN1 guinea pig antiserum showed considerable selectivity, binding only the homologous isolate TN1 when used as the de-

TABLE 3. Serological characterization of Bean common mosaic virus (BCMV) isolates using strain-specific antibodies in triple-antibody sandwich enzyme-linked immunosorbent assay (ELISA) ${ }^{\mathrm{a}}$

\begin{tabular}{lccccc}
\hline & \multicolumn{5}{c}{ BCMV strains } \\
\cline { 2 - 6 } Antibodies & TN1 & NY15P & US10 & JMB & JMC \\
\hline Pre-immune & - & - & - & - & - \\
Anti-NY15p & - & + & + & - & - \\
Anti-US10 & + & + & + & + & + \\
Anti-TN1 & + & - & - & - & - \\
\hline
\end{tabular}

a Symbols: + designates ELISA signal (absorbance at $405 \mathrm{~nm}$ ) in an infected plant exceeding healthy control $\geq 10$-fold; - designates ELISA signal in an infected plant equal to a healthy control.

TABLE 2. Primers used for cloning the whole Bean common mosaic virus (BCMV) genome

\begin{tabular}{|c|c|c|}
\hline Primer & Sequence $\left(5^{\prime}-3^{\prime}\right)$ & Use \\
\hline \multicolumn{3}{|l|}{ Degenerate primers } \\
\hline HPFor & TGYGAYAAYCARYTIGAYIIIAAYG & Degenerate primer to amplify partial HC-Pro gene \\
\hline HPRev & GAICCRWAIGARTCIAIIACRTG & Degenerate primer to amplify partial HC-Pro gene \\
\hline CIFor & GGIVVIGTIGGIWSIGGIAARTCIAC & Degenerate primer to amplify partial CI gene \\
\hline CIRev & ACICCRTTYTCDATDATRTTIGTIGC & Degenerate primer to amplify partial CI gene \\
\hline NIbFor & GGICARCCITCIACIGTIGT & Degenerate primer to amplify partial NIb gene \\
\hline \multicolumn{3}{|r|}{ - } \\
\hline $\mathrm{N} 1 \mathrm{~T}$ & GACCACGCGTATCGATGTCGAC(T) $)_{17} \mathrm{~V}$ & Generic $3^{\prime}$ end first-strand primer \\
\hline N1 & GACCACGCGTATCGATGTCGAC & Generic $3^{\prime}$ end PCR primer \\
\hline \multicolumn{3}{|c|}{ 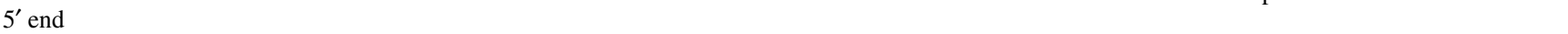 } \\
\hline Oligo d(T) Anchor primer & GACCACGCGTATCGATGTCGAC(T) ${ }_{16} \mathrm{~V}$ & \\
\hline \multicolumn{3}{|l|}{ RU1_OR specific primers } \\
\hline RU1__OR mg1 For & CAACAACTTCTCGCAACCAACCAC & Specific primer to amplify the major gap 1 \\
\hline RU1_OR mg1 Rev & СCСTTTGCCCATTAGGATTCCTCC & Specific primer to amplify the major gap 1 \\
\hline RU1_OR mg2 For & GAGTCCAACTAAGAGACACC & Specific primer to amplify the major gap 2 \\
\hline RU1_OR mg2 Rev & CACGTCCTGGTGGTGTTGCTGATAC & Specific primer to amplify the major gap 2 \\
\hline RU1_OR mg3 For & GTATCAGCAACACCACCAGGACGTG & Specific primer to amplify the major gap 3 \\
\hline RU1_OR mg3 Rev & TCCGGTGAAGTGCCATTGTCAATAC & Specific primer to amplify the major gap 3 \\
\hline RU1_OR 5RACE Rev1 & CTTAGCGCGCGCCATTCCTGC & First-strand primer for $5^{\prime}-\mathrm{RACE}$ \\
\hline RU1_OR 5RACE Rev2 & GTGGCACAGTGATTGTTCC & PCR primer for $5^{\prime}$-RACE \\
\hline \multicolumn{3}{|l|}{ US10 specific primers } \\
\hline US10 mg1 For & CAACAACTTCTCGCAACCAACCAC & Specific primer to amplify the major gap 1 \\
\hline US10 mg1 Rev & CTGTATTTGCTATAACCTTCCG & Specific primer to amplify the major gap 1 \\
\hline US10 mg2 For & CCATCCAGAAACCAGAAGTGC & Specific primer to amplify the major gap 2 \\
\hline US10 mg2 Rev & CAGCGAGAGGTCGTGTTGG & Specific primer to amplify the major gap 2 \\
\hline US10 mg3 For & GTCGAGATCAACACAATGGG & Specific primer to amplify the major gap 3 \\
\hline US10 mg3 Rev & CGCTCTTGTATGTCCTCATCGC & Specific primer to amplify the major gap 3 \\
\hline US10 5RACE Rev1 & TGATACCСТCTCTCACCCC & First-strand primer for $5^{\prime}$-RACE \\
\hline \multicolumn{3}{|l|}{ RU1_P specific primers } \\
\hline RU1_P mg1 For & CAACAACTTCTCGCAACCAACCAC & Specific primer to amplify the major gap 1 \\
\hline RU1_P mg1 Rev & CCCTTTGCCCATTAGGATTCCTCC & Specific primer to amplify the major gap 1 \\
\hline RU1_P mg2 For & GAGTCCAACTAAGAGACACC & Specific primer to amplify the major gap 2 \\
\hline RU1_P mg2 Rev & CACGTCCTGGTGGTGTTGCTGATAC & Specific primer to amplify the major gap 2 \\
\hline RU1_P mg3 For & GTATCAGCAACACCACCAGGACGTG & Specific primer to amplify the major gap 3 \\
\hline RU1_P mg3 Rev & TCCGGTGAAGTGCCATTGTCAATAC & Specific primer to amplify the major gap 3 \\
\hline RU1_P 5RACE Rev1 & CACTTTGCCGATGTATTCCTTCTG & First-strand primer for $5^{\prime}$-RACE \\
\hline RU1_P 5RACE Rev2 & GTCTCCACTTCTATGAACTCACCAAC & PCR primer for $5^{\prime}$-RACE \\
\hline
\end{tabular}

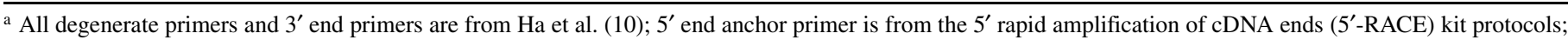
$\mathrm{PCR}=$ polymerase chain reaction . 
tecting antibody. The anti-NY15P guinea pig antiserum was able to bind the homologous isolate NY15P and one heterologous isolate US10. The data presented in Table 3 indicated that there was some cross-reactivity between different strains of BCMV and BCMNV in TAS-ELISA and in Western blots due to close relationship between BCMV and BCMNV. Nevertheless, JMB and JMC isolates displayed a clear serological distinction from the US10 isolate, despite identical pathotypes as determined on a set of bean differential cultivars (Table 1).

Whole-genome cloning, sequencing, and sequence analysis. The whole genomes of BCMV isolates JMB and JMC were cloned separately, initially using RT-PCR amplification of three conserved regions characteristic of potyviruses through the use of degenerate primers, as described in Materials and Methods. The three initial clones were sequenced and, surprisingly, were found

TABLE 4. Nucleotide and amino acid differences between RU1-OR-B and RU1-OR-C isolates of Bean common mosaic virus

\begin{tabular}{lcc}
\hline & \multicolumn{2}{c}{ Change (RU1-OR-B/RU1-OR-C) } \\
\cline { 2 - 3 } Position $^{\mathrm{a}}$ & Nucleotide & Amino acid \\
\hline 2,726 & $\mathrm{~A} / \mathrm{C}$ & - \\
2,735 & $\mathrm{G} / \mathrm{A}$ & - \\
2,744 & $\mathrm{G} / \mathrm{A}$ & - \\
3,777 & $\mathrm{G} / \mathrm{C}$ & $\mathrm{A} / \mathrm{P}$ \\
5,799 & $\mathrm{G} / \mathrm{A}$ & V/I \\
6,287 & $\mathrm{G} / \mathrm{A}$ & - \\
6,289 & $\mathrm{~A} / \mathrm{G}$ & $\mathbf{K} / \mathbf{R}$ \\
6,301 & $\mathrm{~A} / \mathrm{G}$ & $\mathbf{K} / \mathbf{R}$ \\
6,323 & $\mathrm{C} / \mathrm{T}$ & - \\
6,360 & $\mathrm{C} / \mathrm{G}$ & $\mathrm{H} / \mathrm{D}$ \\
6,413 & $\mathrm{~A} / \mathrm{G}$ & - \\
6,463 & $\mathrm{C} / \mathrm{T}$ & $\mathrm{P} / \mathrm{L}$ \\
6,507 & $\mathrm{~A} / \mathrm{G}$ & $\mathrm{K} / \mathrm{E}$ \\
6,515 & $\mathrm{~A} / \mathrm{G}$ & - \\
6,550 & $\mathrm{~A} / \mathrm{G}$ & $\mathbf{K} / \mathbf{R}$ \\
6,571 & $\mathrm{~A} / \mathrm{G}$ & $\mathrm{N} / \mathrm{S}$ \\
7,663 & $\mathrm{~A} / \mathrm{T}$ & $\mathrm{E} / \mathrm{V}$ \\
7,964 & $\mathrm{G} / \mathrm{A}$ & - \\
8,398 & $\mathrm{~T} / \mathrm{C}$ & $\mathrm{V} / \mathrm{A}$ \\
8,876 & $\mathrm{C} / \mathrm{T}$ & - \\
9,004 & $\mathrm{G} / \mathrm{A}$ & $\mathrm{S} / \mathbf{N}$ \\
9,041 & $\mathrm{C} / \mathrm{T}$ & - \\
9,056 & $\mathrm{~T} / \mathrm{C}$ & - \\
\hline
\end{tabular}

a Position of nucleotide in whole genome.

${ }^{\mathrm{b}}$ Bold designates chemically similar amino acids. to be 98 to $99 \%$ identical to the known sequence of the BCMV strain RU1. Two large gaps between clones BCMV-HP and BCMV-NIb were filled in via RT-PCR amplification, using specific primers as listed in Table 2. The large 5 'terminal clone BCMV-mg1 was obtained through RT-PCR amplification using specific primers based on the RU1 sequence (BCMV isolate RU1-D, GenBank accession GQ219793). The very 5'-terminal sequences for both JMB and JMC were obtained through the use of the 5'-RACE technique, as described in Materials and Methods. Upon sequence assembly, both JMB and JMC were found to be 9,984 nucleotides (nt) long, excluding the poly (A). The two sequences were nearly identical, with only 23 nt differences $(\approx 99.8 \%$ nucleotide identity) resulting in 12 amino-acid (aa) changes in the entire genome (Table 4); 6 of these amino-acid changes were chemically conserved. Because of this high level of identity between the two sequences, a single name was retained, BCMV RU1-OR. Based on conceptual translation, the BCMV RU1-OR genome encoded a single polyprotein of 3,196 aa. The sequences of RU1-OR-B and RU1-OR-C were compared with the known BCMV and BCMNV genomes using the BLAST tool, and the comparison revealed that both the RU1-OR-B and $-\mathrm{C}$ sequences shared the closest similarity to the sequence referred to as RU1-D (accession number GQ219793; 98 to 99\% nucleotide identity), except for a small fragment near the $5^{\prime}$ terminus (see below).

Two other BCMV isolates, US10 and RU1-P, were sequenced using the same approach. The full-length BCMV US10 genome was cloned, sequenced, and found to be 9,998-nt long. The BCMV US10 genome encoded a single polyprotein of 3,201 aa. A control RU1 isolate, RU1-P (pathotype VI), was also cloned and sequenced. The whole genome of RU1-P was found to be $10,003 \mathrm{nt}$ long, coding for a single polyprotein of 3,202 aa. The RU1-P sequence was almost identical to RU1-D, with only $44 \mathrm{nt}$ changes $(\approx 99.6 \%$ identity) for the entire genome.

The whole genomes for RU1-OR, RU1-P, RU1-W, RU1-D, and US10 were aligned using the CLUSTALX program and subjected to a recombination analysis using the RDP4 package of programs. The comparison of all known RU1 whole-genome sequences plus the sequence of US10 using the manual distance plot analysis are shown in Figure 2, with the full-length BCMV RU1-D sequence from the GenBank as the reference.

The RDP4 analysis demonstrated that the 5'-terminal fragment of the RU1-OR genome (nucleotides 1 to 722 ) was dissimilar

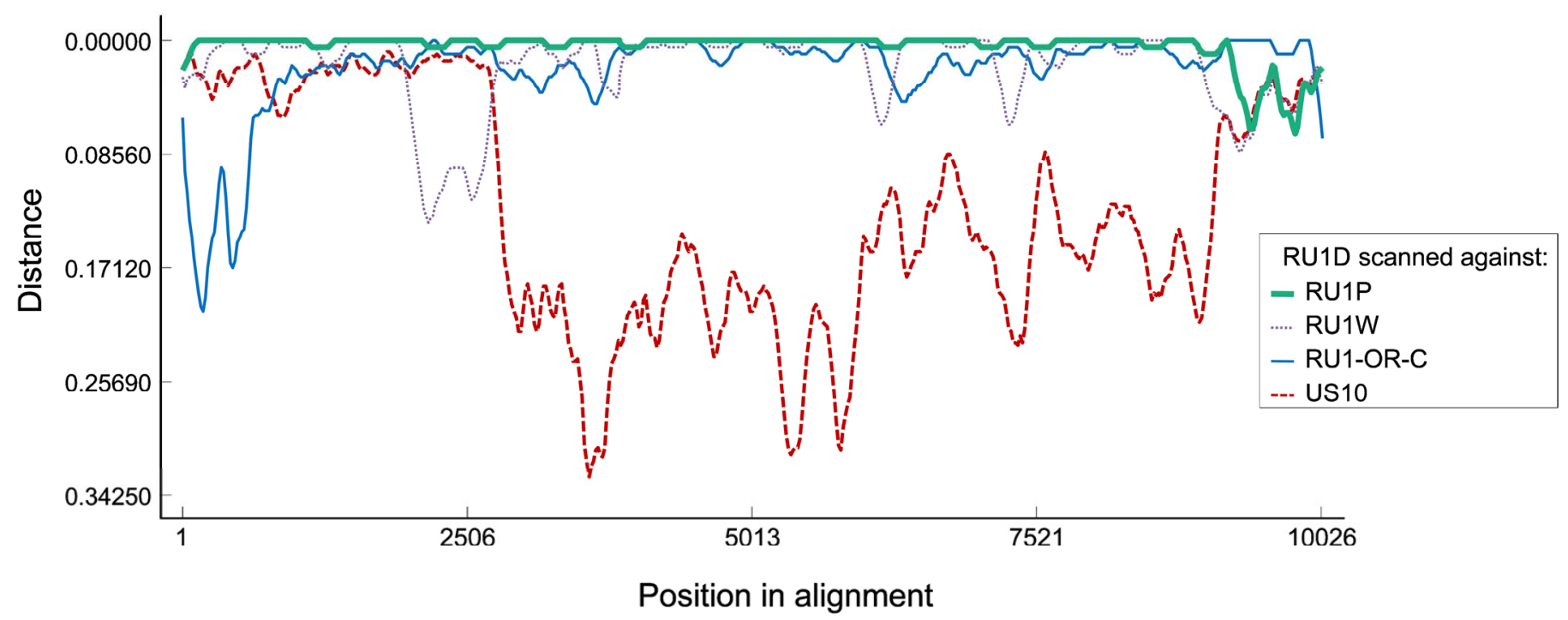

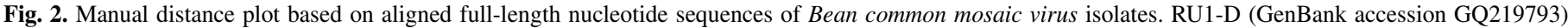

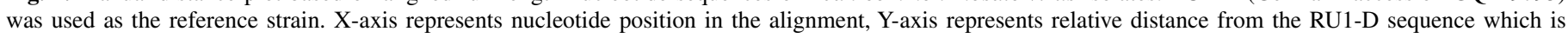
calculated using the Kimura model. 
from other RU1 sequences and also from the US10 sequence (Fig. 2). The downstream segment spanning nucleotides 723 to 1,976 (position in alignment) was nearly identical (98\%) for RU1-OR and US10 on the one hand and among RU1-D, RU1-P, and RU1-W on the other hand (99\% identity). The identity level between these two groups in the same region was $96 \%$. A fragment of the RU1-W genome between nucleotides 1,977 and 2,720 was highly dissimilar from all other sequences analyzed (Fig. 2). A large section of the US10 genome, nucleotides 2,721 to 9,114 , displayed a more distant relationship to the RU1-OR and other RU1 sequences (Fig. 2). In the 3'-terminal region, downstream of nucleotide 9,120 (position in alignment), RU1-D and RU1-OR on the one hand and RU1-P, RU1-W, and US10 on the other hand formed two distinct similarity groups. These patterns of similarity and dissimilarities are presented in Figure 3.

\section{DISCUSSION}

Potyviruses are a large family of positive-strand RNA viruses well known for their propensity to rapid evolution through accumulation of mutations and extensive recombination (9). Thus, recombination is one of the factors that allowed potyviruses to adapt to various hosts and different environments in order to survive and spread. The genetic diversity of some potyviruses, such as Tobacco vein banding mosaic virus (52), Zucchini yellow mosaic virus (23), Turnip mosaic virus $(37,47,48)$, Potato virus $Y$ (PVY) (14-16,25), or Soybean mosaic virus (SMV) (40), has been well documented, and genetic determinants involved in interactions with resistance genes had been identified in Wheat streak mosaic virus (WSMV) (45), PVY $(34,46,49)$, and SMV $(6,12,39)$. However, until recently, BCMV and BCMNV genetic diversity was not revealed to the same extent as in other potyviruses, despite an extremely well-developed genetics of BCMV resistance in common bean $(5,42)$. Thus far, only a few whole genomes for BCMV and BCMNV had been published $(21,22$, $35,36)$. A natural recombinant of BCMNV, NL-3K, was described by Larsen et al. (21), carrying a small insert of the BCMV RU1 sequence near the $5^{\prime}$ terminus of the otherwise BCMNV genome; this recombinant was associated with more severe symptoms on certain bean cultivars $(7,21,30,44)$.

RU1 is currently known as the only TSN isolate of BCMV assigned to pathogroup VI $(21,31)$. The original RU1 strain was intercepted in mid-1980s in a dry bean entry imported from Russia $(28,29,31)$. Since then, it was confined to the lab, staying in the Prosser, WA virus collection, and was never reported from the field. Two complete genome sequences of RU1 were deposited in the GenBank database: the RU1-W sequence was published by Larsen et al. (21) and the RU1-D sequence was published by Naderpour et al. (36). Interestingly, both RU1-D and RU1-W sequences came from the same virus collection maintained in Prosser, WA. This indicates a substantial diversity in the original BCMV-RU1 strain intercepted in that dry bean shipment (31).

In this article, we describe a novel BCMV isolate, RU1-OR, which was collected from L192 field-grown bean in the Willamette Valley, OR. Hence, our RU1-OR represents the first example of an RU1 strain found in the field in North America, and perhaps first in the entire world. Initial biological typing on a panel of bean indicators defined RU1-OR as a pathotype VII isolate (Table 1) capable of overcoming one of the most advanced resistance genes, $b c-2^{2}(5,42)$. Biologically, RU1-OR was found identical to the control isolate US10, displaying the same pathotype VII (Table 1). However, because serological properties between US10 and RU1-OR did not match (Table 3), the genomes of both US10 and RU1-OR were cloned, sequenced, and compared with each other and with other related sequences available in public databases. RU1-OR was found very close to the previously sequenced isolates RU1-D and RU1-W, which displayed a TSN pathotype VI $(21,31,35,36)$. The sequence dissimilarities found between RU1-OR and US10 in the capsid protein (CP) region (Figs. 2 and 3), especially in the $5^{\prime}$-terminal area of the cistron, may account for the serological distinction

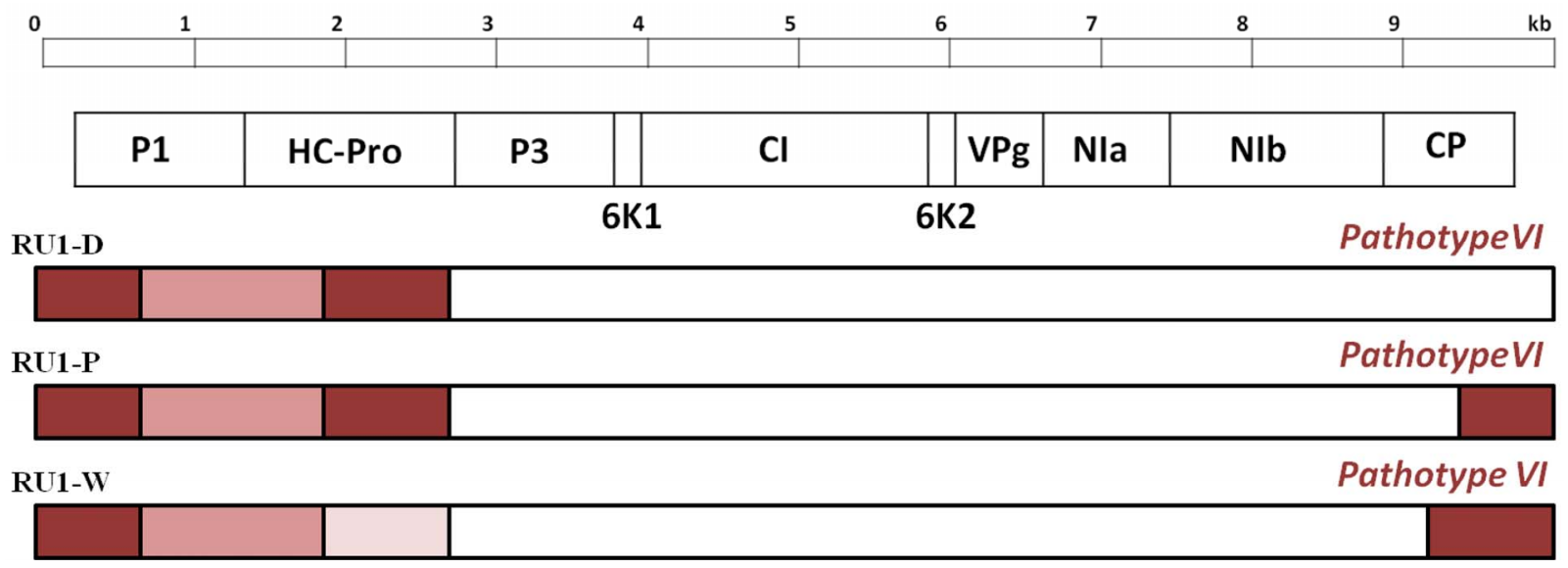

RU1-OR

Pathotype VII

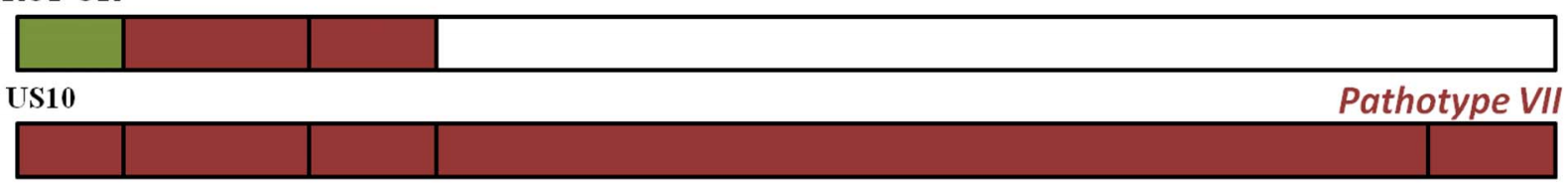

BCMV-RU1

BCMV-US10

Fig. 3. Schematic diagram showing putative Bean common mosaic virus (BCMV) recombination positions between US10 and an unknown BCMV parent. Putative recombinant junctions are shown as vertical lines. Shading of the different sections of the sequenced BCMV genomes reflects similarity or dissimilarity level as presented on Figure 2: highly similar genome sections are shaded in the same color, while dissimilar sections are shaded in a different color. 
found between these two BCMV isolates (Table 3). It was demonstrated previously that the $\mathrm{N}$-terminal one-third of potyvirus CPs harbored most of the strain-specific epitopes $(32,41)$. This apparent disconnect in serological differences between US10 and RU1-OR (Table 3) on the one hand and an identical pathotype (Table 1) on the other hand may suggest that the region of the BCMV genome responsible for the interactions with the recessive $b c-2$ and $b c-2^{2}$ genes lies outside of the CP gene.

Closely related molecular characteristics of RU1-OR and other RU1 isolates, and clearly different reactions toward $b c-2$ and $b c-2^{2}$ genes, make them perfect candidates to search for genetic determinants responsible for the expression of BCMV pathotypes VI and VII in common bean. All RU1 isolates studied displayed the same symptoms on the first three indicator bean lines carrying recessive genes $b c-u, b c-1$, or $b c-1^{2}$ : Stringless Green Refugee (HG 1), Redlands Greenleaf C (HG 2), and Redlands Greenleaf B (HG 3). The only difference observed was that RU1-OR could infect bean lines carrying $b c-u$ and $b c-1^{2}$ or $b c-2^{2}$ resistance genes instead of $b c-u$ and $b c-2$ for RU1-P (Table 1). When inspecting the RU1-OR pathogenicity profile and our genome analysis, it appears that the region spanning the $\mathrm{C}$-terminal half of $\mathrm{P} 1$ and the $\mathrm{N}$-terminal part of HC-Pro in pathotype VII isolates may interact with the $b c-2^{2}$ gene (Fig. 3). However, all the hypotheses on the locations of genetic determinants responsible for interactions with BCMV resistance genes in bean need to be tested using reverse genetic tools.

Many previous reports suggested that P1 and HC-Pro were both multifunctional proteins involved in important aspects of virushost interactions in potyviruses $(26,38)$. Klein et al. (18) found that an insertion mutant in the $\mathrm{P} 1$ region of Tobacco vein mottling virus was able to modulate disease symptoms. Recent reversegenetics experiments demonstrated that the HC-Pro cistron of PVY is involved in triggering both $N c$ (34) and $N y$ (46) genes in potato and induction of necrosis. HC-Pro region was also demonstrated to be involved in host specificity and virulence of WSMV (43). Reverse genetics also revealed the role of HC-Pro and P3 cistrons in overcoming resistance to SMV in soybean $(6,51)$. NL$3 \mathrm{~K}$, the natural recombinant of BCMNV carrying an $\approx 350$-nt insert of the BCMV RU1 sequence in the P1 cistron, caused more severe symptoms on selected common bean lines $(7,21,30,44)$. A possible recombination event between Blackeye cowpea mosaic virus and BCMV found in the $5^{\prime}$-terminal region $\left(5^{\prime}\right.$ untranslated region and $\mathrm{P} 1$ ) in two isolates of BCMV from asparagus bean (Vigna unguiculata spp. sesquipedalis L.) was linked to symptom modulation in this host (53). The differences found in the P1 region among three strains of BYMV (BYMV, BYMV-MB4, and BYMV-S) were linked to the uncharacteristic symptom expression and host range changes (13). Thus, our data showing that the P1-HC-Pro region of BCMV may be involved in interactions with the $b c-2^{2}$ gene are consistent with previous research conducted on other potyviruses.

The data presented here suggest that recombination between BCMV strains may be quite common, and BCMV RU1 represents multiple recombinants, with isolates sometimes changing their pathotypes. Of the sequences analyzed, US10 may be considered the most likely parental strain while other parents have yet to be identified (Fig. 3). With a limited number of whole-genome sequences available for BCMV isolates at the moment, it is difficult, thus far, to appreciate the entire spectrum of the BCMV genetic diversity and its role in BCMV pathogenicity.

\section{ACKNOWLEDGMENTS}

This work was funded, in part, through grants from the Idaho Bean Commission and the Idaho State Department of Agriculture, and by the Idaho Agricultural Experiment Station. We thank P. Berger, P. Shiel, and J. Crosslin for providing reference isolates of BCMV; and C. Strausbaugh and S. Singh for many helpful discussions.

\section{LITERATURE CITED}

1. Adams, M. J., Zerbini, F. M., French, R., Rabenstein, F., Stenger, D. C., and Valkonen, J. P. T. 2011. Family Potyviridae. Pages 1069-1089 in: Virus Taxonomy. Ninth Rep. Int. Committee on Taxonomy of Viruses. A. King, M. Adams, E, Carstens, and E. Lefkowitz, eds. Elsevier, Oxford.

2. Altschul S. F., Madden T. L., Schaffer A., Zhang J., Zhang Z., Miller W., and Lipman D. J. 1997. Gapped BLAST and PSI-BLAST: a new generation of protein database search programs. Nucleic Acids Res. 25:33893402.

3. Berger, P. H., Wyatt, S. D., Shiel, P. J., Silbernagel, M. J., Druffel, K., and Mink, M. I. 1997. Phylogenetic analysis of the Potyviridae with emphasis on legume-infecting potyviruses. Arch. Virol. 142:1979-1999.

4. Clark, M. F., and Adams, A. N. 1977. Characteristics of the microplate method of enzyme-linked immunosorbent assay for the detection of plant viruses. J. Gen. Virol. 34:475-483.

5. Drifjhout, E. 1978. Genetic Interaction Between Phaseolus vulgaris and Bean Common Mosaic Virus with Implications for Strain Identification and Breeding for Resistance. Centre for Agricultural Publication and Documents, Wageningen, The Netherlands.

6. Eggenberger, A. L., Hajimorad, M. R., and Hill, J. H. 2008. Gain of virulence on Rsvl-genotype soybean by an avirulent Soybean mosaic virus requires concurrent mutations in both $\mathrm{P} 3$ and HC-Pro. Mol. PlantMicrobe Interact. 21:931-936.

7. Fang, G. W., Allison, R. F., Zambolim, E. M., Maxwell, D. P., and Gilbertson, R. L. 1995. The complete nucleotide sequence and genome organization of bean common mosaic virus (NL3 strain). Virus Res. 39:13-23.

8. Flores-Estevez, N., Acosta-Gallegos, J. A., and Silva-Rosales, L. 2003. Bean common mosaic virus and Bean common mosaic necrosis virus in Mexico. Plant Dis. 87:21-25.

9. Gibbs, A., and Ohshima, K. 2010. Potyviruses and the digital revolution. Annu. Rev. Phytopathol. 48:205-223.

10. Ha, C., Coombs, S., Revill, P. A., Harding, R. M., Vu, M., and Dale, J. L. 2008. Design and application of two novel degenerate primer pairs for the detection and complete genomic characterization of potyviruses. Arch. Virol. 153:25-36.

11. Haggard, J. E., and Myers, J. R. 2007. Interspecific hybrids developed by Herbert Lamprecht: a source of disease resistance for common bean. Annu. Rep. Bean Improv. Coop. 50:7-8.

12. Hajimorad, M. R., Eggenberger, A. L., and Hill, J. H. 2005. Loss and gain of elicitor function of Soybean mosaic virus G7 provoking Rsv1-mediated lethal systemic hypersensitive response maps to P3. J. Virol. 79:12151222.

13. Hammond, J., and Hammond, R. W. 2003. The complete nucleotide sequence of isolate BYMV-GDD of Bean yellow mosaic virus, and comparison to other potyviruses. Arch. Virol. 148:2461-2470.

14. Hu, X., Meacham, T., Ewing, L., Gray, S. M., and Karasev, A. V. 2009. A novel recombinant strain of Potato virus $Y$ suggests a new viral genetic determinant of vein necrosis in tobacco. Virus Res. 143:68-76.

15. Karasev, A. V., and Gray, S. M. 2013. Continuous and emerging challenges of Potato virus $Y$ in potato. Annu. Rev. Phytopathol. 51:571-586.

16. Karasev, A. V., and Gray, S. M. 2013. Genetic diversity of Potato virus $Y$ complex. Am. J. Potato Res. 90:7-13.

17. Karasev, A. V., Nikolaeva, O. V., Hu, X. J., Sielaff, Z., Whitworth, J., Lorenzen, J. H., and Gray, S. M. 2010. Serological properties of ordinary and necrotic isolates of Potato virus $Y$ : a case study of $\mathrm{PVY}^{\mathrm{N}}$ misidentification. Am. J. Potato Res. 87:1-9.

18. Klein, P. G., Klein, R. R., Rodríguez-Cerezo, E., Hunt, A. G., and Shaw, J. G. 1994. Mutational analysis of the tobacco vein mottling virus genome. Virology 204:759-769.

19. Lamprecht, H. 1935. Komplexe und homologe Mutationen insbesondere bei Phaseolus vulgaris, Ph. multiflorus und Pisum sativum. Hereditas 20:273-288.

20. Lamprecht, H. 1948. On the effect and linkage of genes transmitted from Phaseolus coccineus to Ph. vulgaris. Agric. Hortic. Genet. 6:64-81

21. Larsen, R. C., Druffel, K. L., and Wyatt, S. D. 2011. The complete nucleotide sequences of Bean common mosaic necrosis virus strains NL-5, NL-8 and TN-1. Arch. Virol. 156:729-732.

22. Larsen, R. C., Miklas, P. N., Druffel, K. L., and Wyatt, S. D. 2005. NL-3 $\mathrm{K}$ Strain is a stable and naturally occurring interspecific recombinant derived from Bean common mosaic necrosis virus and Bean common mosaic virus. Phytopathology 95:1037-1042.

23. Lecoq, H., Wipf-Scheibel, C., Chandeysson, C., Lê Van, A., Fabre, F., and Desbiez, C. 2009. Molecular epidemiology of Zucchini yellow mosaic virus in France: an historical overview. Virus Res. 141:190-200.

24. Leiser, R. M., and Richter, J. 1978. Purification and some characteristics of potato virus Y. Arch. Phytopathol. Pflanzenschutz 14:337-350.

25. Lorenzen, J. H., Meacham, T., Berger, P. H., Shiel, P. J., Crosslin, J. M., Hamm, P. B., and Kopp, H. 2006. Whole genome characterization of 
Potato virus $Y$ isolates collected in the western USA and their comparison to isolates from Europe and Canada. Arch. Virol. 151:1055-1074.

26. Maia, I. G., Haenni, A., and Bernardi, F. 1996. Potyviral HC-Pro: a multifunctional protein. J. Gen. Virol. 77:1335-1341.

27. Martin, D. P., Williamson, C., and Posada, D. 2005. RDP2: recombination detection and analysis from sequence alignments. Bioinformatics 21:260262.

28. McKern, N. M., Mink, G. I., Barnett, O. W., Mishra, A., Whittaker, L. A., Silbernagel, M. J., Ward, C. W., and Shukla, D. D. 1992. Isolates of Bean common mosaic virus comprising two distinct potyviruses. Phytopathology 82:923-929.

29. McKern, N. M., Ward, C. W., and Shukla, D. D. 1992. Strains of bean common mosaic virus consist of at least two distinct potyviruses. Arch. Virol. Suppl. 5:407-414.

30. Miklas, P. N., Strausbaugh, C. A., Larsen, R. C., and Forster, R. L. 2000. NL-3 (K) - a more virulent strain of NL-3 and its interaction with $b c-3$. Annu. Rep. Bean Improv. Coop. 43:168-169.

31. Mink, G. I., and Silbernagel, M. J. 1992. Serological and biological relationships among viruses in the bean common mosaic virus subgroup. Arch. Virol. Suppl. 5:397-406.

32. Mink, G. I., Vetten, H. J., Wyatt, S. D., Berger, P. H., and Silbernagel, M. J. 1999. Three epitopes located on the coat protein amino terminus of viruses in the bean common mosaic potyvirus subgroup. Arch. Virol. 144:1173-1189.

33. Morales, F. J., and Bos, L. 1988. Bean common mosaic virus. Descriptions of Plant Viruses, No. 337. http://www.dpvweb.net/dpv/ showdpv.php?dpvno=337

34. Moury, B., Caromel, B., Johansen, E., Simon, V., Chauvin, L., Jacquot, E., Kerlan, C., and Lefebvre, V. 2011. The helper component proteinase cistron of Potato virus $Y$ induces hypersensitivity and resistance in Potato genotypes carrying dominant resistance genes on chromosome IV. Mol. Plant-Microbe Interact. 24:787-797.

35. Naderpour, M., and Johansen, I. E. 2011. Visualization of resistance responses in Phaseolus vulgaris using reporter tagged clones of Bean common mosaic virus. Virus Res. 159:1-8.

36. Naderpour, M., Lund, O. S., and Johansen, I. E. 2009. Sequence analysis of expressed cDNA of Bean common mosaic virus RU1 isolate. Iran J. Virol. 3:41-43.

37. Ohshima, K., Yamaguchi, Y., Hirota, R., Hamamoto, T., Tomimura, K., Tan, Z., Sano, T., Azuhata, F., Walsh, J.A., Fletcher, J., Chen, J., Gera, A., and Gibbs, A. J. 2002. Molecular evolution of Turnip mosaic virus: evidence of host adaptation, genetic recombination and geographical spread. J. Gen. Virol. 83:1511-1521.

38. Rohožková, J., and Navrátil, M. 2011. P1 peptidase-a mysterious protein of family Potyviridae. J. Biosci. 36:189-200.

39. Seo, J. K., Lee, S. H., and Kim, K. H. 2009. Strain-specific cylindrical inclusion protein of Soybean mosaic virus elicits extreme resistance and a lethal systemic hypersensitive response in two resistant soybean cultivars. Mol. Plant-Microbe Interact. 22:1151-1159.
40. Seo, J. K., Ohshima, K., Lee, H. G., So, M., Choi, H. S., Lee, S. H., Sohn, S. H., and Kim, K. H. 2009. Molecular variability and genetic structure of the population of Soybean mosaic virus based on the analysis of complete genome sequences. Virology 393:91-103.

41. Shukla, D. D., Tribbick, G., Mason, T. J., Hewish, D. R., Geysen, H. M., and Ward, C. W. 1989. Localization of virus-specific and group-specific epitopes of plant potyviruses by systematic immunochemical analysis of overlapping peptide fragments. Proc. Natl. Acad. Sci. USA 86:8192-8196.

42. Singh, S., and Schwartz, H. F. 2010. Breeding common bean for resistance to diseases: a review. Crop Sci. 50:2199-2223.

43. Stenger, D. C., and French, R. 2004. Functional replacement of Wheat streak mosaic virus HC-Pro with the corresponding cistron from a diverse array of viruses in the family Potyviridae. Virology 232:257-267.

44. Strausbaugh, C. A., Miklas, P. N., Singh, S. P., Myers, J. R., and Forster, R. L. 2003. Genetic characterization of differential reactions among host group 3 common bean cultivars to NL-3 K strain of Bean common mosaic necrosis virus. Phytopathology 93:683-690.

45. Tatineni, S., Van Winkle, D. H., and French, R. 2011. The N-terminal region of Wheat streak mosaic virus coat protein is a host- and strainspecific long-distance transport factor. J. Virol. 85:1718-1731.

46. Tian, Y. P., and Valkonen, J. P. 2013. Genetic determinants of Potato virus $Y$ required overcoming or trigger hypersensitive resistance to PVY strain group $\mathrm{O}$ controlled by the gene $\mathrm{Ny}$ in potato. Mol. Plant-Microbe Interact. 26:297-305

47. Tomimura, K., Špak, J., Katis, N., Jenner, C. E., Walsh, J. A., Gibbs, A. J., and Ohshima, K. 2004. Comparisons of the genetic structure of populations of Turnip mosaic virus in West and East Eurasia. Virology 330:408423.

48. Tomitaka, Y., and Ohshima, K., 2006. A phylogeographic study of the Turnip mosaic virus population in East Asia reveals an 'emergent' lineage in Japan. Mol. Ecol. 15:4437-4457.

49. Tribodet, M., Glais, L., Kerlan, C., and Jacquot, E. 2005. Characterization of Potato virus $Y$ (PVY) molecular determinants involved in the vein necrosis symptom induced by $\mathrm{PVY}^{\mathrm{N}}$ isolates in infected Nicotiana tabacum cv. Xanthi. J. Gen. Virol. 86:2101-2105.

50. Vetten, H. J., Lesemann, D. E., and Maiss, E. 1992. Serotype A and B strains of bean common mosaic virus are two distinct potyviruses. Arch. Virol. Suppl. 5:415-431.

51. Wen, R. H., Khatabi, B., Ashfield, T., Saghai Maroof, M. A., and Hajimorad, M. R. 2013. The HC-Pro and P3 cistrons of an avirulent Soybean mosaic virus are recognized by different resistance genes at the complex Rsv1 locus. Mol. Plant-Microbe Interact. 26:203-215.

52. Zhang, C. L., Gao, R., Wang, J., Zhang, G. M., Li, X. D., and Liu, H. T. 2011. Molecular variability of Tobacco vein banding mosaic virus populations. Virus Res. 158:188-198.

53. Zheng, H., Chen, J., Chen, J., Adams, M. J., and Hou, M. 2002. Bean common mosaic virus isolates causing different symptoms in asparagus bean in China differ greatly in the 5'-parts of their genomes. Arch. Virol. 147:1257-1262. 